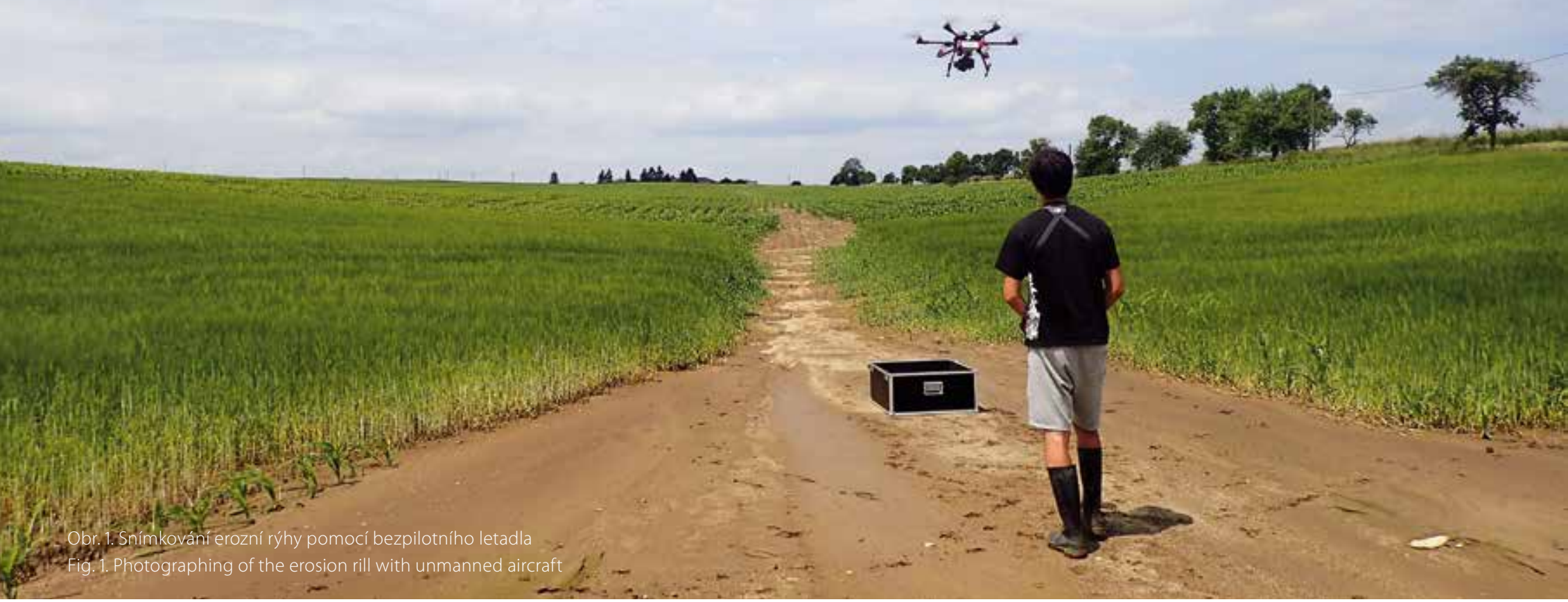

\title{
Stanovení odnosu půdy z rýhové eroze metodou digitální fotogrammetrie a metodou volumetrické kvantifikace
}

\section{JANA UHROVÁ, RADEK BACHAN, PAVLA ŠTĚPÁNKOVÁ}

Klíčová slova: digitální fotogrammetrie - volumetrická kvantifikace - rýhová eroze digitální model terénu - bezpilotní letecké prostředky - odnos půdy

\section{SOUHRN}

Článek představuje dvě rozdílné metody měření rýhové eroze, která patř́ k častým důsledkům extrémních srážkových úhrnů. Na vybrané lokalitě, postižené výraznou rýhovou erozí, byly pomocí volumetrické kvantifikace a blízké fotogrammetrie zdokumentovány projevy eroze způsobené prívalovými srážkami. Volumetrická kvantifikace je metodou prímého měření terénu. Pomocí speciálního zařizení - erodoměru - jsou ve vybraných místech zaměřeny příčné profily průběhu terénu, na základě kterých je pak vypočítána celková hodnota rýhové eroze. Metody blízké fotogrammetrie jsou založeny na snímkování zájmové lokality pomocí bezpilotního letadla. Pořízené fotografie následně slouží k vytvoření digitálního modelu terénu (DMT), jeho analýzou je poté zjištěn objem erodovaného materiálu. Srovnání těchto postupů pak proběhlo s využitím príčných řezů terénem vyneseným fotogrammetrií v místech fyzického měření erodoměrem.

\section{ÚVOD}

Rýhová eroze patři $v$ našich podmínkách $k$ rozšírenému typu poškození půdy. Tento typ vodní výmolové eroze ohrožuje zejména svažité zemědělské pozemky. Míra ohrožení stoupá, pokud je povrch půdy bez vegetačního pokryvu, prípadně s výsadbou širokořádkových plodin (kukuřice, řepa, brambory apod.). Spouštěčem rýhové eroze bývá nejčastěji prívalový déšt. Srážky nejprve odtékají po povrchu, následně se soustředují do jednotlivých rýh a celá situace může vyústit v soustředěný odtok vody. Při tomto jevu dochází k odnosu nejúrodnější části půdy a poškození daného zemědělského pozemku, prípadně i odnosu sadby.

Kvantifikace odnesené půdy slouží ke stanovení prímých škod způsobených na pozemku, kdy vlivem eroze dochází k odstraňování úrodné orniční vrstvy a tím ke snižování produkční schopnosti pưdy. Zhoršují se její fyzikální, biologické ale i chemické vlastnosti půdy [1]. 
Měření eroze půdy je možné provádět pomocí volumetrické kvantifikace s využitím tzv. erodoměru - přístroje pro záznam průběhu povrchu půdy ve vybraném profilu. Toto zařizení bylo nejprve využito pro stanovení ztráty pưdy, ke které došlo při těžbě dřeva [2]. Dále byl erodoměr používán v různých modifikacích. Napríklad $v$ hornatých oblastech Blaney a Warrington [3] pracovali s erodoměrem, který zaměřval pouze deset bodů pro jeden príčný profil. V České republice začal erodoměr pro stanovení objemu odnesené půdy využivat tým v Ústavu vodního hospodářství krajiny Fakulty stavební VUT v Brně pod vedením profesora Dumbrovského [4, 5], kde stále probíhá vývoj prístroje i postupů zaznamenávání a vyhodnocení erozních odnosů půdy při rýhové erozi.

Neprímou metodu stanovení objemu eroze predstavují bezpilotní letecké prostředky (UAV), které mohou být použivány k dálkovému průzkumu Země (DPZ) a umožňují sledování objektů a zemského povrchu bez přímého fyzického kontaktu [6]. UAV v dnešní době umožňují přesné, rychlé a relativně levné podklady pro vyhodnocení eroze na zemědělských plochách. Díky metodám fotogrammetrie a SfM (Structure from Motion) je možné zpracovat sadu neuspořádaných a různě se překrývajících snímků a rekonstruovat tak trojrozměrné modely, ze kterých Ize následně měřit parametry erozních rýh (hloubka, šírka, délka) a stanovit objem odnesené půdy či vytvářet 3D modely současného i původního terénu. Metodami SfM se podrobně ve své práci zabývá napríklad Westoby a kol. [7].

UAV byly pro monitoring časových změn půdního povrchu a intenzity eroze půdy využity např. v letech 2012 a 2013 Eltnerovou a kol. [8]. Další studie od Pierzchala [9] využila snímkování pomocí bezpilotních letadel ke sledováni objemu přemístěné zeminy při těžbě dřeva. V České republice se pak na výzkum erozního poškození půd pomocí metod DPZ zaměřuje ve své práci Vláčilová a Krása [10]. V současnosti se pak optimalizací monitoringu eroze zemědělské půdy a postupy kvantifikace erodovaného materiálu s využitím bezpilotních letadel zabývá např́iklad Katedra hydromeliorací a krajinného inženýrství ČVUT v Praze ve spolupráci s Výzkumným ústavem meliorací a ochrany půdy, v. v. i., a Českým hydrometeorologickým ústavem v projektu s názvem Vývoj automatizovaného nástroje pro optimalizaci monitoringu eroze zemědělské půdy pomocí distančních metod.

Brněnské pracoviště Výzkumného ústavu vodohospodářského T. G. Masaryka, v. v. i., provádí výzkum v oblasti možného stanovení míry odnosu erodovaného materiálu ze zemědělsky využívaných ploch pomocí metod digitální fotogrammetrie a volumetrické kvantifikace s následným porovnáním získaných výsledků. Tento príspěvek popisuje první výsledky záznamu rýhové eroze a jejího vyhodnocení pomocí výstupů dvou výše uvedených metod na vybrané pilotní lokalitě.

\section{MATERIÁLY A METODY HODNOCENÍ}

\section{Metody digitální fotogrammetrie}

K měření rýhové eroze pomocí bezpilotního letadla se využíá metody blízké fotogrammetrie. Vlastní postup se skládá ze snímkování povrchu terénu, následného zpracování pořizených snímků a vytvoření podrobného digitálního modelu terénu, ze kterého se provede výpočet objemu odnesené půdy [11].

Snímkovaná zájmová oblast musí být před vlastním vzletem bezpilotního letadla (obr. 1) vyznačena vlícovacími body (obr. 2), které je nezbytné přesně polohově zaměřit pomocí geodetických přístrojů. Naměřené souřadnice vlícovacích bodů a jejich nadmořské výšky slouží k prípadné korekci nepřesností vlastních snímků a ke georeferencování vytvářeného modelu terénu. U pořízených snímků terénu je nezbytný překryv z 60-80 \%. Jen tak je zabezpečeno bezproblémové spojení získaných fotografií, které usnadní další dílči zpracování dat a zvýší přesnost konečného výsledku.

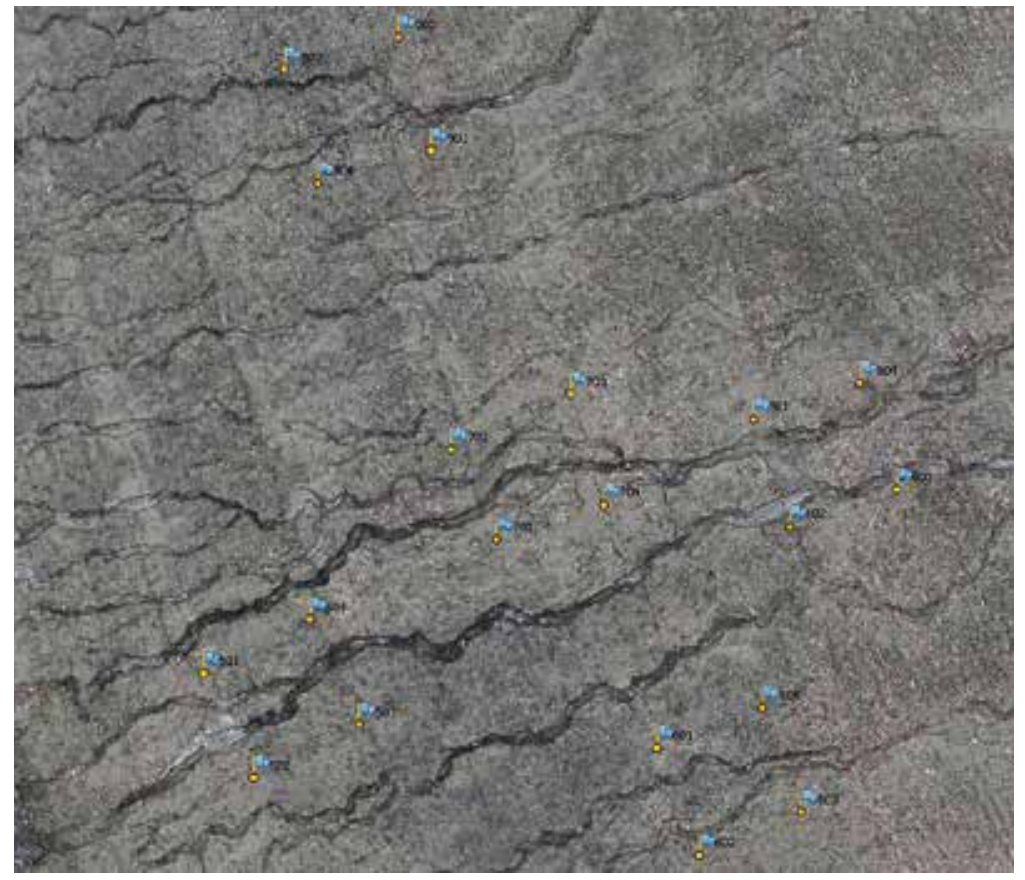

Obr. 2. Zájmová lokalita s vyznačenými vlícovacími body

Fig. 2. The location of interest with marked ground control points

Po práci v terénu následuje již vlastní zpracování snímků metodou SfM pomocí specializovaného softwaru (např. Agisoft PhotoScan Professional). Program je schopen identifikovat polohy, směry a náklony fotoaparátu umístěného na bezpilotním letadle [12]. Výstupem jsou data ve formátu ASCII nebo bodová vrstva s XYZ souřadnicemi, které je možné dále zpracovávat v prostředích GIS. Zde Ize zvolit ideální velikost rozlišení modelu, který se pro samotné zpracování může stát zásadním. Samotný výpočet objemu erozních rýh je pak založen na stanovení objemu prostoru mezi teoretickým pưvodním terénem a terénem po odnosu půdy, který byl zaměřen bezpilotním letadlem a následně vymodelován. Podobnými postupy a využitím UAV při kvantifikaci objemů erodovaného materiálu se věnuje ve své publikaci Glendell a kol. [13].

\section{Metoda prímé volumetrické kvantifikace}

Volumetrická kvantifikace rýhové eroze na ploše pozemku představuje metodu přímého měření průběhu terénu. Pro jeho zaznamenání je využíaán erodoměr - zařízení umožňující zaměření prríčného profilu průběhu terénu. Použitý typ měřicího zařízení byl vyvinut v Ústavu vodního hospodářství krajiny Fakulty stavební VUT v Brně [4]. Při kvantifikaci rýhové eroze se záznam průběhu terénu provádí ve čtvercovém rámu o rozměru $2 \times 2 \mathrm{~m}$ (obr. 3), v němž je vyneseno pět profilů $v$ celé šírce čtvercového pole v pravidelných vzdálenostech (cca 0,33 m). Čtvercový rám s erodoměrem je umístován na erozí zasažený svah. Povrch půdy vyznačují jehlice v celé šírce erodoměru (1 m), jejichž horní části po spuštění na terén kopírují průběh povrchu půdy. Ten je zdokumentován pomocí fotoaparátu a převeden do digitální podoby ve formě grafu, který dále slouží ke stanovení objemu erozních rýh [5].

\section{Vyhodnocení erozního odnosu na pilotní lokalitě Šardice}

Katastr obce Šardice (okres Hodonín) byl v únoru 2017 postižen erozí z náhlého tání sněhu, kdy vznikly poměrně výrazné souběžné erozní rýhy. Lokalita se nacházela jižně od intravilánu obce nad Šardickým potokem s půdami o hlavní 


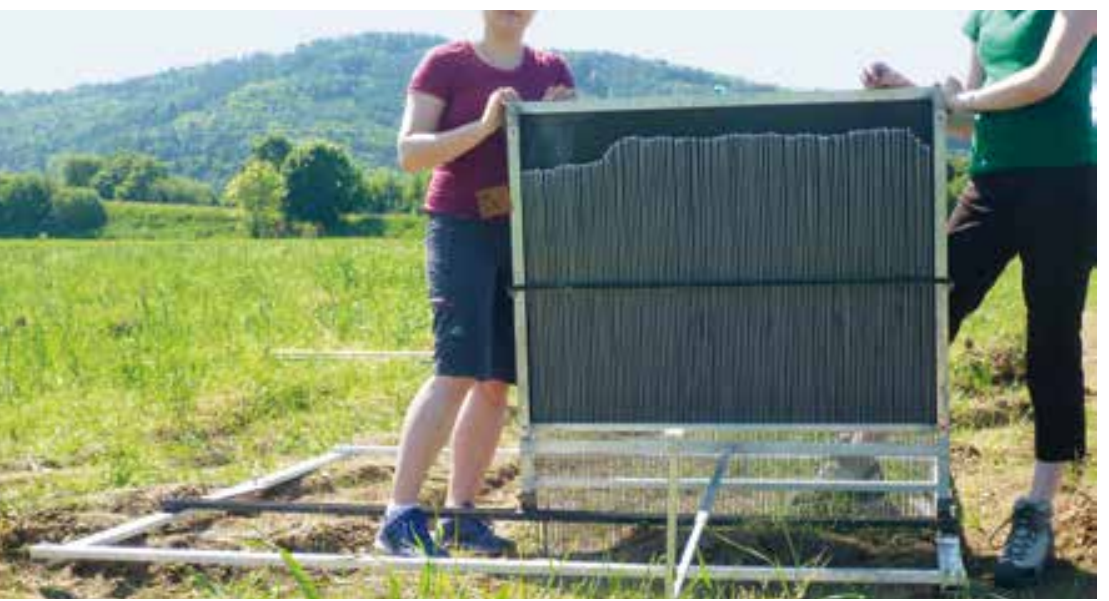

Obr. 3. Záznam průběhu terénu pomocí erodoměru s využitím čtvercového pole Fig. 3. Record the terrain course using the soil erosion bridge with the use of a square field

půdní jednotce (HPJ) 08, popsané jako černozemě modální a černozemě pelické, hnědozemě, luvizemě, popř. i kambizemě luvické, smyté. Následky eroze byly dokumentovány jak prímou metodou volumetrické kvantifikace (erodoměr), tak i s využitím blízké fotogrammetrie (UAV).

Nejprve bylo metodou prímého měření zaznamenáno 25 příčných profilů erozních rýh - v pěti čtvercích $(2 \times 2 \mathrm{~m})$ rozmístěných tak, aby zachytily výrazné projevy rýhové eroze. Vlícovacími body pro snímkování pomocí UAV byla jednak vymezena zájmová oblast, ale také i vrcholy jednotlivých měřících čtverců pro volumetrickou metodu (obr. 4). Na základě terénního průzkumu, velikosti snímaného území a požadované přesnosti výsledků byla pro pilotní lokalitu optimální výška letu stanovena na $10 \mathrm{~m}$ nad terénem. Z pořizených snímků byl vytvořen DMT povrchu pưdy a v místech, kde probíhalo prímé měření pomocí erodoměru, byly vytvořeny př́čné řezy DMT pro následné porovnání. $V$ prípadě pilotní lokality byla velikost pixelu modelu DMT určena na velikost $1 \mathrm{~cm}$, tato vzdálenost odpovídá rozlišení prì metodě volumetrické kvantifikace.
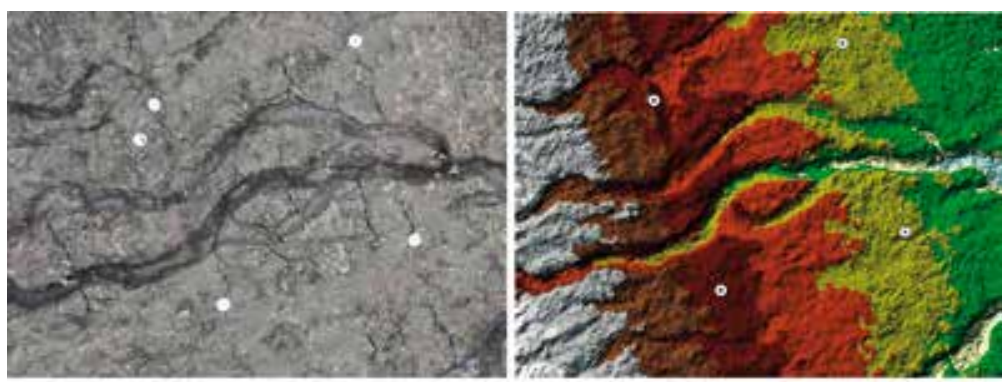

Obr. 4. Ortofoto snímek a DMT erozních rýh s vlícovacími body pro jeden ze čtverců měřených erodoměrem

Fig. 4. Ortofoto image and DMT erosion rill with ground control points for one of the squares measured by a soil erosion bridge

\section{VÝSLEDKY A DISKUSE}

Základním výstupem volumetrické metody je záznam jednotlivých príčných profilů erozních rýh (obr. 5). Pro srovnání obou metod bylo nezbytné vynést z fotogrammetrických výstupů shodné príčné profily (umístění, rozsah). Srovnání výstupů získaných oběma metodami ukazuje dobrou shodu v průběhu těchto linií (obr. 6). Z jednotlivých příčných profilů je ž̌ejmé, že výsledky získané metodou blízké fotogrammetrie shlazují do určité míry tvar terénu, a to především v případě kolmých stěn erozních zářezů.
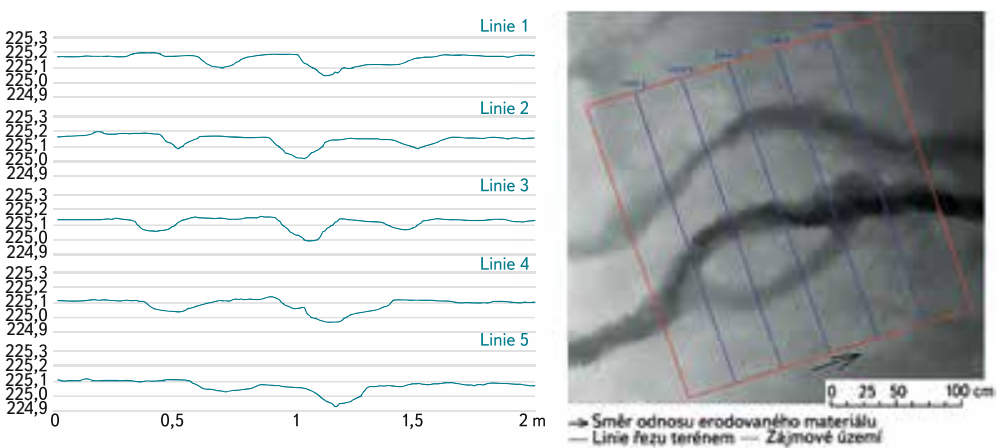

Obr. 5. Príčné profily erozních rýh získané pomocí erodoměru

Fig. 5. Cross profile of erosion rills obtained by using a soil erosion bridge
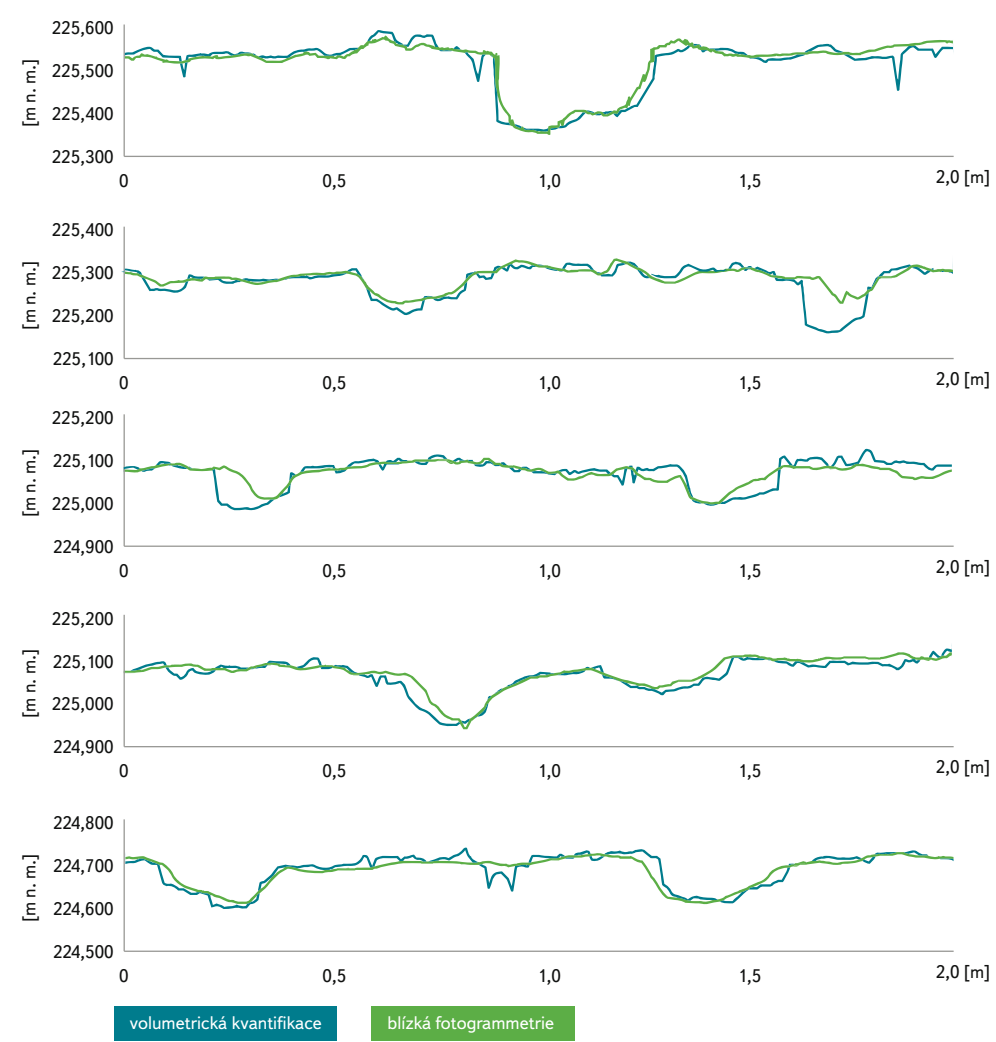

Obr. 6. Srovnání príčných profilů erozních rýh získaných pomocí volumetrické kvantifikace (erodoměr) a bezpilotního letadla (blízká fotogrammetrie)

Fig. 6. Comparison of transverse profiles of erosion rills obtained by volumetric quantification (soil erosion bridge) and unmanned aircraft (close-up photogrammetry)

Dosavadní zkušenosti uváděné v literatuře předpokládaly, že odhad objemu erodovaného materiálu měřeného prímou metodou pomocí erodoměru bude až dvojnásobný ve srovnání s postupy blízké fotogrammetrie (bezpilotní letadlo) [10]. První srovnání výstupů z pilotní lokality v Šardicích tyto předpoklady nepotvrzují, průběh příčných profilů ve čtyřech z pěti měřených čtverců vykazuji dobrou shodu. K vyneseným řezům byl pro prvotní stanovení odnosu ze čtverců při hodnocení volumetrické kvantifikace vynesen řez z digitálního modelu reliéfu ČR 5. generace [14]. Následný odnos ze čtverce byl stanoven rozdílem ploch $v$ profilech přepočtených na plochu. Odhad objemu erodovaného materiálu při blízké fotogrammetrii byl stanoven prímo pro plochu každého čtverce, jako rozdíl dvou DMT. První výpočty odnosu uvádí tabulka 1. Z tabulky vyplývají u 4 z 5 čtverců minimální rozdíly při srovnání výsledků stanoveného odnosu půdy. Významnost shody obou metod bude následně 
Tabulka 1. Hodnoty průměrné ztráty pưdy z profilů vynesených terénem v absolutních hodnotách v $m^{3}$ pro jednotlivé čtverce

Table 1. Average soil loss values from terrain profiles in absolute values in $\mathrm{m}^{3}$

\begin{tabular}{llllll} 
& čtverec A & čtverec B & čtverec C & čtverec D & čtverec E \\
\hline blízká fotogrammetrie & 0,1239 & 0,0522 & 0,1312 & 0,1579 & 0,1393 \\
\hline volumetrická kvantifikace & 0,1589 & 0,1261 & 0,1784 & 0,1403
\end{tabular}

stanovena obvyklými statistickými metodami a dalši kroky výzkumu povedou k hledání postupů ke zpřesnění vyčíslení objemu odneseného materiálu oběma metodami.

První srovnání výstupů obou metodik tak ukazuje, že postupy založené na leteckém snímkování mohou být považovány za rovnocenné prímým metodám. Pro jejich širší uplatnění hovoří také, že poskytují spojitý obraz erozní rýhy $\checkmark$ celém jejím průběhu. Je třeba mít na paměti shlazování kolmých stěn erozních zářezů při tvorbě digitálního modelu terénu z orotofoto snímků. Nicméně i metoda volumetrické kvantifikace má svá omezení, kdy může docházet ke zkreslení reálných hodnot při zaznamenávání průběhu terénu pomocí fotoaparátu a jeho následnou interpretaci. Navíc její pracnost a časová náročnost omezuje počet prováděných měření. Podrobné srovnání pozitiv a negativ obou metod je uvedeno $v$ tabulce 2. Další práce $v$ této oblasti budou zaměřeny na možnosti stanovení celkového objemu erodované půdy. Pro obě metody je třeba vyřešit stanovení základní roviny povrchu výchozího terénu před erozní událostí, a to jak její celkový průběh, tak také její vertikální umístění v získaných rezech terénu s projevem eroze.

\section{Tabulka 2. Srovnání výhod a nevýhod jednotlivých stanovení}

Table 2. Comparison of advantages and disadvantages of individual determinations

\section{Volumetrická kvantifikace Digitální fotogrammetrie}

\begin{tabular}{|c|c|c|c|}
\hline+ & - & + & - \\
\hline $\begin{array}{l}\text { Velmi přesný } \\
\text { záznam príčc- } \\
\text { ného profilu } \\
\text { erozní rýhy }\end{array}$ & $\begin{array}{l}\text { Nezbytné tech- } \\
\text { nické vybavení } \\
\text { s náročnou } \\
\text { manipulací }\end{array}$ & $\begin{array}{l}\text { Za relativně krát- } \\
\text { kou dobu je } \\
\text { možné zazname- } \\
\text { nat průběh eroze } \\
\text { na velké ploše }\end{array}$ & $\begin{array}{l}\text { Nezbytné } \\
\text { finančně } \\
\text { náročné tech- } \\
\text { nické vyba- } \\
\text { vení a potřeba } \\
\text { proškoleného } \\
\text { pilota }\end{array}$ \\
\hline
\end{tabular}

Průměrování hodnot objemu eroze na základě několika prričných profilù pro celou délku erozní rýhy

Možnost relativně přesného zpracování velkých oblastí postižených erozi

S rostoucím prostorovým rozsahem eroze klesá přesnost vyhodnocení (průměrování hodnot)
Výstupy ve formě spojité informace na povětrnostních podmínkách (nelze při dešti a silnějším větru)
V současné době jsou za účelem stanovení průběhu původního terénu ověrovány možnosti využití digitálního modelu reliéfu ČR 5. generace [14], a to jak vjednotlivých příčných profilech, tak i na celkové ploše pozemku. Další možností, jak stanovit průběh původního povrchu terénu, je zaměření pozemku po zapravení erozních projevů zemědělskou technikou pomocí digitální fotogrammetrie.

\section{ZÁVĚR}

Erozní procesy mají za následek odstraňování úrodné orniční vrstvy a tím i snižování produkční schopnosti půdy. Stanovení objemu odneseného materiálu představuje jednu z možností vyčíslení prímých škod způsobených na pozemku. Pro stanovení objemu odnesené půdy je možné využít jak přímou volumetrickou metodu pomocí erodoměru, tak také i metody blízké fotogrammetrie pomocí bezpilotního letadla (UAV).

Na pilotní lokalitě v katastrálním území obce Šardice (okres Hodonín) byly pomocí obou uvedených metod zaznamenány projevy eroze z tání sněhu v roce 2017. Hlavním cílem bylo posouzení přesnosti výstupů získaných metodou blízké fotogrammetrie ve srovnání s výstupy z měření erodoměrem. Srovnání prvních výsledků ukázalo, že metody blízké fotogrammetrie poskytují srovnatelné výstupy (průběh prííných profilů terénu) jako záznam erodoměrem. $V$ dalších krocích budou hledány postupy pro zpřesnění stanovení objemu odneseného materiálu pomocí obou metod. Pokud by se prokázalo, že metody blízké fotogrammetrie poskytují dostatečně spolehlivé a přesné výsledky, umožnilo by to širší využití těchto postupů. Jedná se o efektivní, flexibilní, ekonomický i ekologický způsob sběru dat s vysokou přesností. Určitou nevýhodou bezpilotních letadel je v současné době slabá výdrž baterií a s tím spojený omezený dolet stroje a také značná závislost na vhodných povětrnostních podmínkách pro provoz UAV.

Kombinace metod blízké fotogrammetrie a volumetrické kvantifikace tak jak jsou prezentovány, může přispět k lepšímu poznání míry poškození zemědělské půdy erozními jevy. Bezkontaktní postupy navíc umožní získání spojité informace o následcích eroze na velkých plochách v relativně krátkém čase.

\section{Poděkování}

Přispěvek vznikl za podpory projektu CZ.071.02/0.0/0.0/16_023/0000118 Voda pro Prahu rešeného v rámci operačního programu Praha - Pól rưstu ČR.

\section{Literatura}

[1] DUMBROVSKÝ, M. Vliv eroze na produkčni schopnost pưd a pưdní vlastnosti. Disertační práce. Praha: VÚMOP, 1992

[2] RANGER, G.E. and FRANK, F.F. The 3-Ferosion bridge-A new tool for measuring soil erosion. Publication No. 23. Department of Forestry, California, 1978,7 p

[3] BLANEY, D.G. and WARRINGTON, G.E. Estimating soil erosion using an erosion bridge. Colorado, 1983. WSDG-TP-00008. WSDG Report. USDA Forest Services.

[4] DUMBROVSKÝ, M., SOBOTKOVÁ, V., PAVLIKK, F. a UHROVÁ, J. Objemová kvantifikace erozních rýh v povodí Šardického potoka. Littera Scripta, 2011, roč. 4, č. 1, s. 145-154. ISSN 1802-503X.

[5] SOBOTKOVÁ, V. Volumetrická kvantifikace projevů vodni eroze a jejich vliv na komplex vybraných půdních charakteristik. Dizertační práce. Brno, 2012. 121 s.

[6] ŽiŽ̉ALA, D., KRÁSA, J. a kol. Monitoring erozního poškozenípưdv $C_{R}$ nástroji dálkového průzkumu Země. Praha: Výzkumný ústav meliorací a ochrany půdy, v. v. i., 2016. ISBN 978-80-87361-63-4.

[7] WESTOBY, M.J. et al. "Structure-from-Motion" photogrammetry: A low-cost, effective tool for geoscience applications. Geomorphology, 2012. vol. 179, p. 300-314.

[8] ELTNER, A. et al. Multi-temporal UAV data for automatic measurement of rill and interrill erosion on loess soil. Earth Surface Processes and Landforms, 2014. doi: 10.1002/esp.3673. 
[9] PIERZCHALA, M. et al. Estimating Soil Displacement from Timber Extraction Trails in Steep Terrain: Application of an Unmanned Aircraft for 3D Modelling. Forests, 2014, vol. 5, p. 1212-1223.

[10] VLÁČILOVÁ, M. a KRÁSA, J. Monitoring erozního poškození půd a projevů eroze pomocí metod DPZ. Voda a krajina. Praha: České vysoké učení technické v Praze, Fakulta stavební, 2013, s. 311-319. ISBN 978-80-01-05318-8

[11] PAVELKA, K. Fotogrammetrie. Plzeň: Západočeská univerzita, 2003. ISBN 80-7082-972-9.

[12] AGISOFT. About. [online]. [citováno 2018-09-12]. Dostupné z: http://www.agisoft.com/

[13] GLENDELL, M. et al. Testing the utility of structure from motion photogrammetry reconstructions using small unmanned aerial vehicles and ground photography to estimate the extent of upland soil erosion. Earth Surface Processes and Landforms, 2017

[14] ČÚZK. Digitální model reliéfu České republiky 5. generace (DMR 5G) [online]. 2010. [citováno 2018 09-14]. Dostupné z: http://geoportal.cuzk.cz/(S(ov0bod53pfziiljecfc3t3il))/Default.aspx?mode=Text Meta\&side=vyskopis\&metadataID=CZ-CUZK-DMR5G-V\&head_tab=sekce-02-gp\&menu=302

\section{Autoři}

Ing. Jana Uhrová, Ph.D.

凶jana.uhrova@vuv.cz

Mgr. Radek Bachan

凶radek.bachan@vuv.cz

Mgr. Pavla Štěpánková, Ph.D.

凶pavla.stepankova@vuv.cz

Výzkumný ústav vodohospodářský T. G. Masaryka, v. v. i., pobočka Brno

Příspěvek prošel lektorským řízením.

\section{DETERMINATION OF SOIL LOSS FROM EROSION RILLS BY METHOD OF DIGI- TAL PHOTOGRAMMETRY AND METHOD OF VOLUMETRIC QUANTIFICATION}

\section{UHROVA, J.; BACHAN, R.; STEPANKOVA, P.}

TGM Water Research Institute, p. r. i., Brno Branch

Keywords: close-up photogrammetry - method of volume quantification rill erosion - digital terrain model - unmanned aerial vehicles - soil loss

This article presents the first results of the research focused on the recording of rill erosion, and its evaluation using the outputs of the two methods that can be used to determine the soil yield. The consequences of erosion have been documented on a selected pilot site, both as a direct method of volume quantification (using an profile meter - so called soil erosion bridge) and with the use of unmanned aircraft in close-up photogrammetry (UAV). Volumetric quantification of rill erosion on land is a direct field measurement method which was recorded with an soil erosion bridge - a device that allows the direct measurement of the cross section of the terrain. By direct measurement, 25 transverse erosion engraving profiles of $2 \mathrm{~m}$ were recorded, which exhibited significant signs of escape erosion. The site of interest was also captured using UAV. A digital terrain model (DMT) was created from the captured images, and DMT cross-sections for subsequent comparison were created at points where direct erodometric measurements were taken. It has been shown that methods such as soil erosion bridge readings and photogrammetry are highly effective in the measurement and analysis of rill erosion. They are efficient, flexible, economical and environmentally friendly methods for collecting data with great precision. 